\title{
Myths and realities in Seattle
}

\section{ACRL's Third National Conference was a marketplace for new ideas, products and information services.}

\section{$\mathbf{C}$} ool, cloudy weather with scattered drizzles did not dampen the spirits of the 1,750 librarians, exhibitors, and friends who attended ACRL's Third National Conference in Seattle, April 4-7. The sun did show itself once or twice, however, and those of us who were lucky enough to schedule lunch at the top of the Space Needle on Friday afternoon were treated to the beautiful panorama of mountains and waterways that complement the city's skyline.

Academic and research librarians from 46 states, the District of Columbia, 9 Canadian provinces, England, and Australia met in Seattle to hear theme speakers and researchers, to see exhibits and new products, and to experience the cultural and culinary wonders of the Pacific Northwest. As the Conference Committee had hoped, the excellent turnout will enable ACRL to send one free copy of the proceedings, due to be published in hard copy in late summer or early fall, to anyone who registered for the full conference (others will be able to purchase a copy at a price to be announced later).

\section{The speakers}

The conference theme, "Academic Libraries: Myths and Realities," was chosen to emphasize immediate issues and problems in librarianship and to avoid random speculation about dark, rosy, or at best hazy futures. The first theme speaker was Kaye Gapen, dean of the University of Alabama Library, who went so far as to identify the future itself as a myth. "The future is a combination of myth and reality that can only be addressed as it arrives," she said. "By being proactive, purposive, problem-solving organizations, libraries can act in the present out of concern for the future."

Gapen quoted John Naisbitt's Megatrends to spotlight some of the ways in which university li- braries can deal with change and sort out myths from future realities: more long-range planning at all staff levels; looser organizational structure with decision-making at lower levels; expanded local area networks that link office and classroom to information systems; and greater recognition of the library not as a package delivery business (book storage and retrieval) but as an information delivery business.

However, Paul Olum, president of the University of Oregon and one of three academic administrators that made up the second theme session, considered package delivery, especially of current periodicals, to be the most important function of a research library. "The library is a medium for the current exchange of ideas," Olum said, "not just for the finished collected wisdom to be set down imperishably for posterity." As such, Olum would prefer to reduce both library and teaching faculty in a period of retrenchment rather than reduce acquisitions.

Olum also felt that decision-making should be shared by the library, the university administration, and a faculty library committee. Just as a government might not wish to leave the waging of a war to the generals, he said, a university administration might choose not to give librarians absolute control over the library.

Joe Rushing, chancellor of Tarrant County Junior College, disagreed, labeling as a myth the idea that the faculty knows best. "A myth can be a beautiful thing," Rushing said. "Without mythology the riches of our literature would be surely diminished. But management based on myth is no way to run a railroad-nor a library."

Gresham Riley, president of Colorado College, also disagreed with Olum and explained that li- 


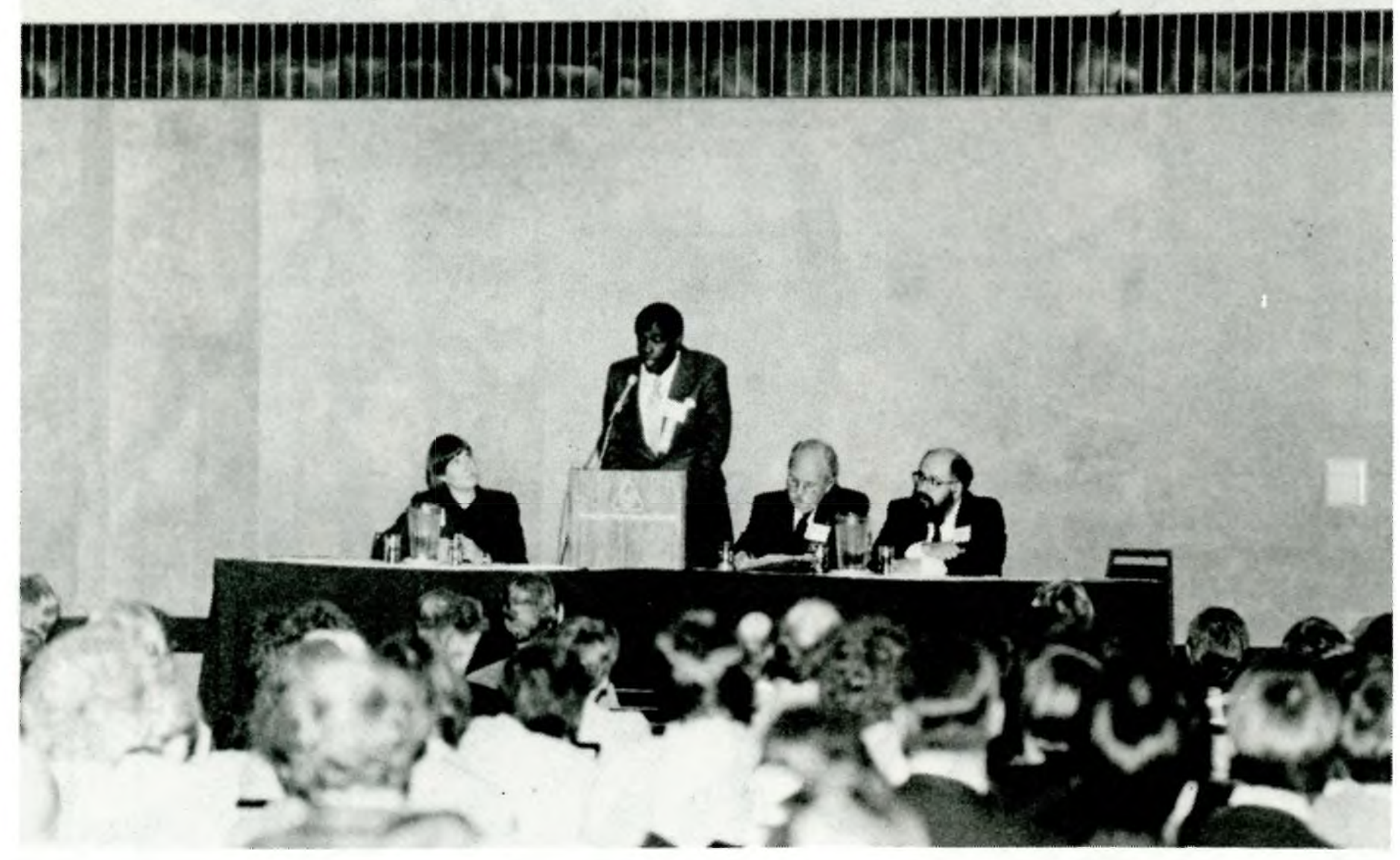

The library user's panel: (l-r) Susan P. Smith, moderator; William Parson; Ronald Jeffels; and David Buerge.

working can display any information you want on your home microcomputer screen. However, David Buerge, an independent scholar and historian of the Duwamish Indians of the Seattle area, pointed out the extreme elusiveness of some resources that can only be discovered serendipitously. Since academic library collections usually reflect the school curriculum, certain research areas of local or special interest are ignored. "In past years this has included ethnic studies and women's studies," Buerge said, "but now these have come into their own." Local and regional folklore and religious studies are two largely ignored areas, he said, that will become much more important to academic collections.

Another speaker that focused on the perspective of the library user was Ronald Jeffels, principal of the Canadian Open Learning Institute. Jeffels reminisced about the colorful and idiosyncratic librarians he has known who in their own way have personified library myths - from the prairie school principal who zealously guarded the library cabinet "with the haughty manner of a feudal lord," to the Cambridge librarian who with fury contained demonstrated to Jeffels the proper way to turn the pages of rare books, "gently, like a knowing lover with a shy lady on a narrow bed."

William Parson, a microbiologist at Evergreen State College, encouraged public services librarians to become information advocates. The new reality, he said, is that they must anticipate the needs of both traditional and non-traditional users, even to the extent of becoming subtly and creatively subversive in the face of university administrators not fully supportive of proactive programs.

In the final theme session, William A. Moffett, Oberlin College librarian, examined the plight of the college librarian in the present crisis of higher education. Likening academia to "a spectacle fit for a Roman arena," in which the universities are huge well-fed lions hectored by their keepers with sticks labeled Government Regulation and Retrenchment, the community colleges are fast-food vendors hawking their specialties in the audience, and the four-year colleges are "frightened figures huddled in clusters around the periphery," Moffett explained that smaller institutions are preoccupied with survival strategies in days of dwindling enrollment.

One prevailing myth, Moffett said, is the University Library Syndrome which implies that quality of education is proportional to the size of an institution. "Life in the minor leagues fosters a set of self-fulfilling low expectations," he said, "but there certainly is life this side of ARL." He quoted one study that ranked colleges and universities together by the percentage of their undergraduates who went on to obtain Ph.Ds and in which eight of the top ten institutions were liberal arts colleges. "Liberal arts colleges no longer prevail, but they do endure. . . . There is special satisfaction that comes of knowing that the investment of their time, their 


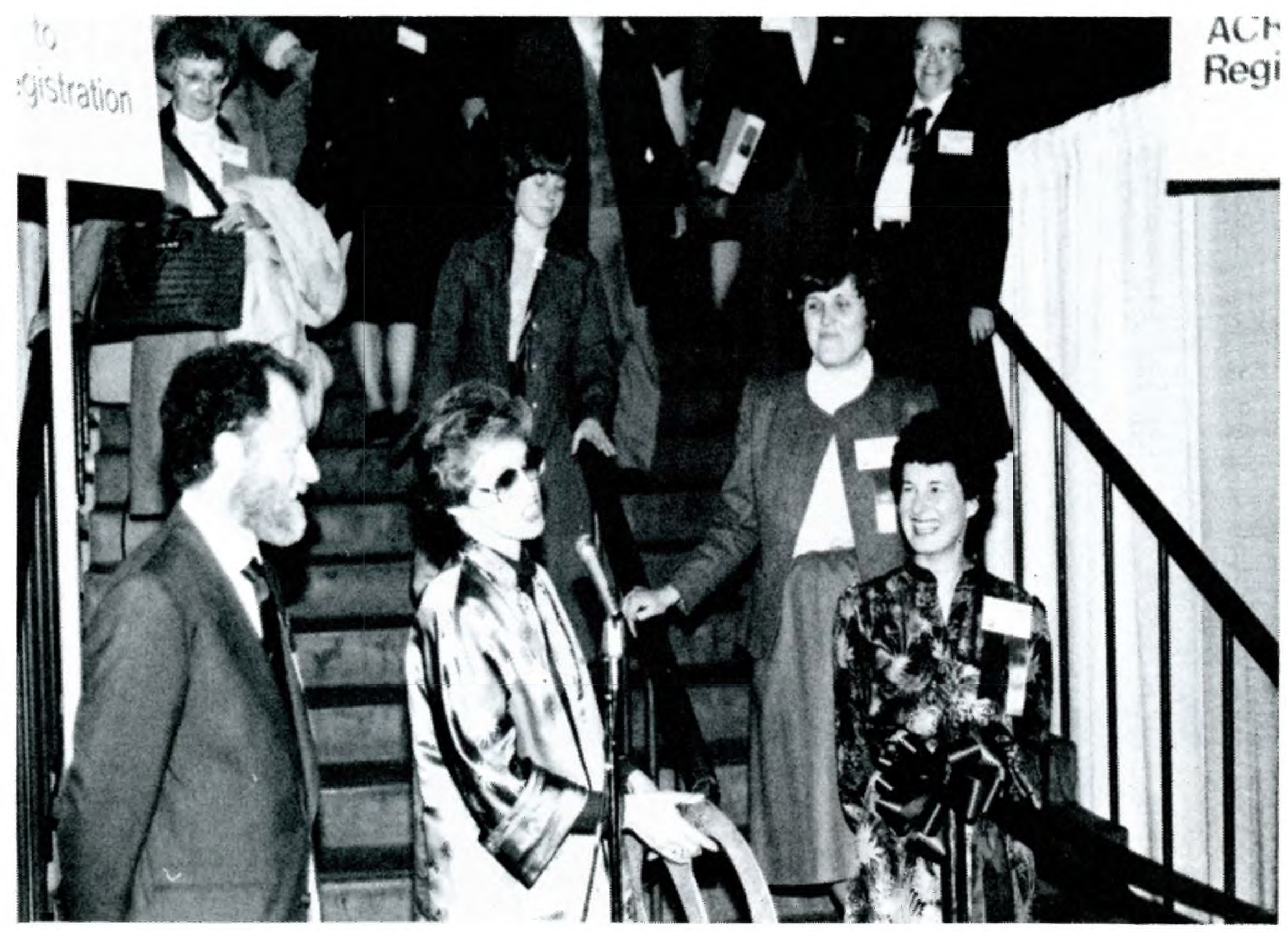

ACRL president Joyce Ball prepares to cut the ribbon for the Exhibits Reception as (l-r) Gary Menges, Sandy Whiteley, and Julie Virgo look on.
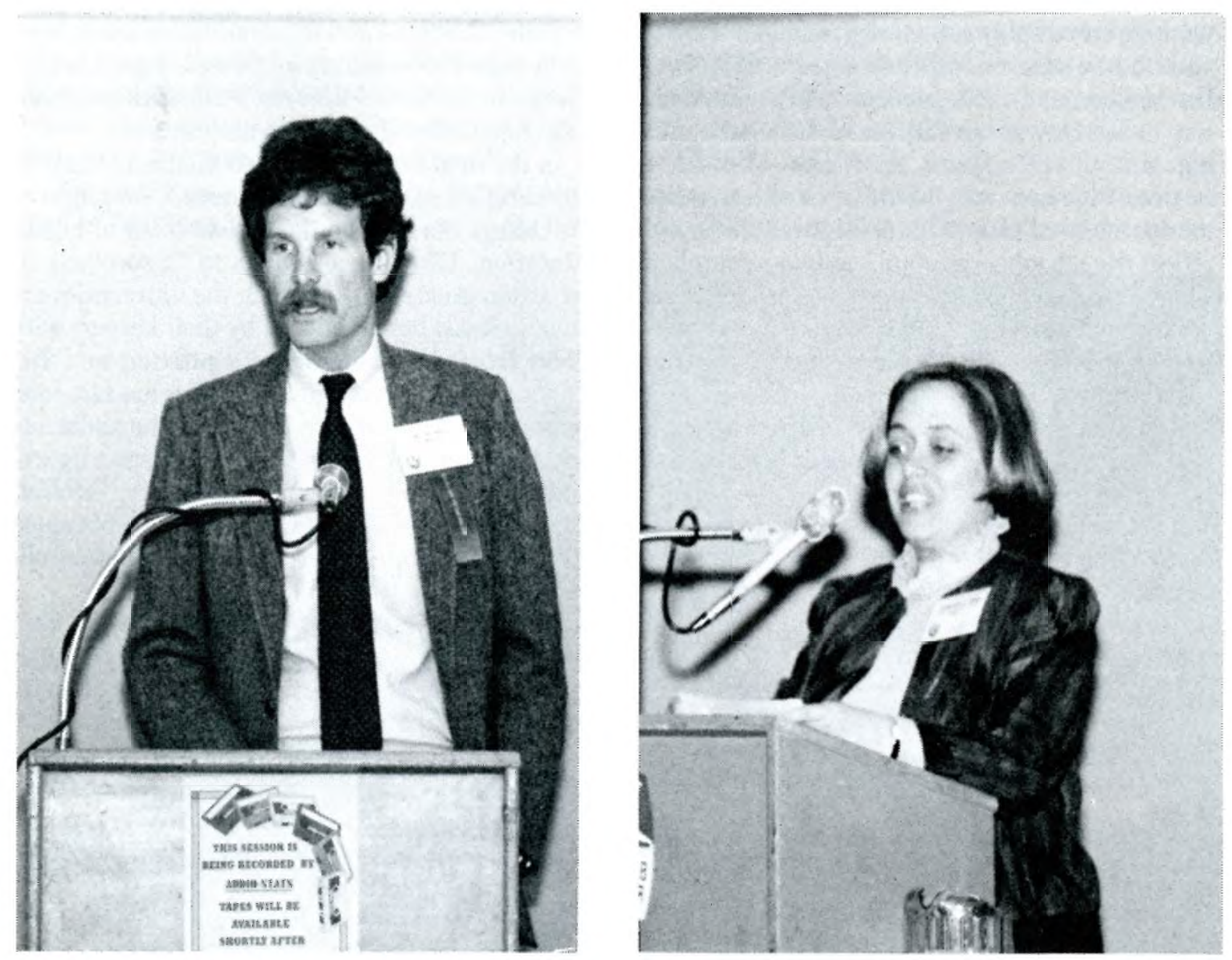

Contributed paper authors: (l) W. Lee Hisle, Austin Community College, on Learning Resource Services, and (r) Barbara J. Ford, University of Illinois at Chicago, on values and ACRL. 


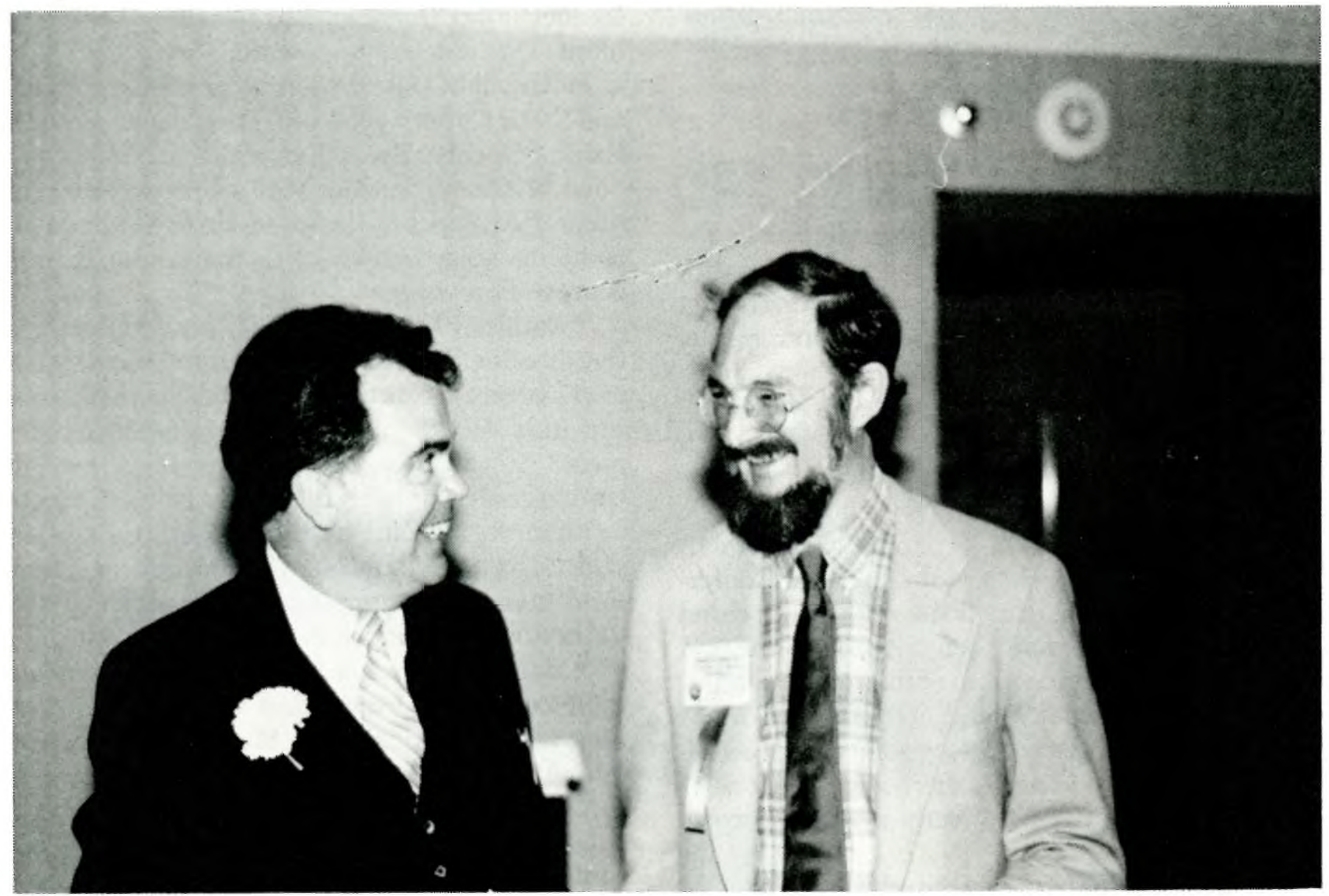

The outgoing and incoming editors of College \& Research Libraries share a laugh at a conference reception: (l) C. James Schmidt, Research Libraries Group, former editor, and ( $r$ ) Charles Martell, California State University, Sacramento, the current editor.

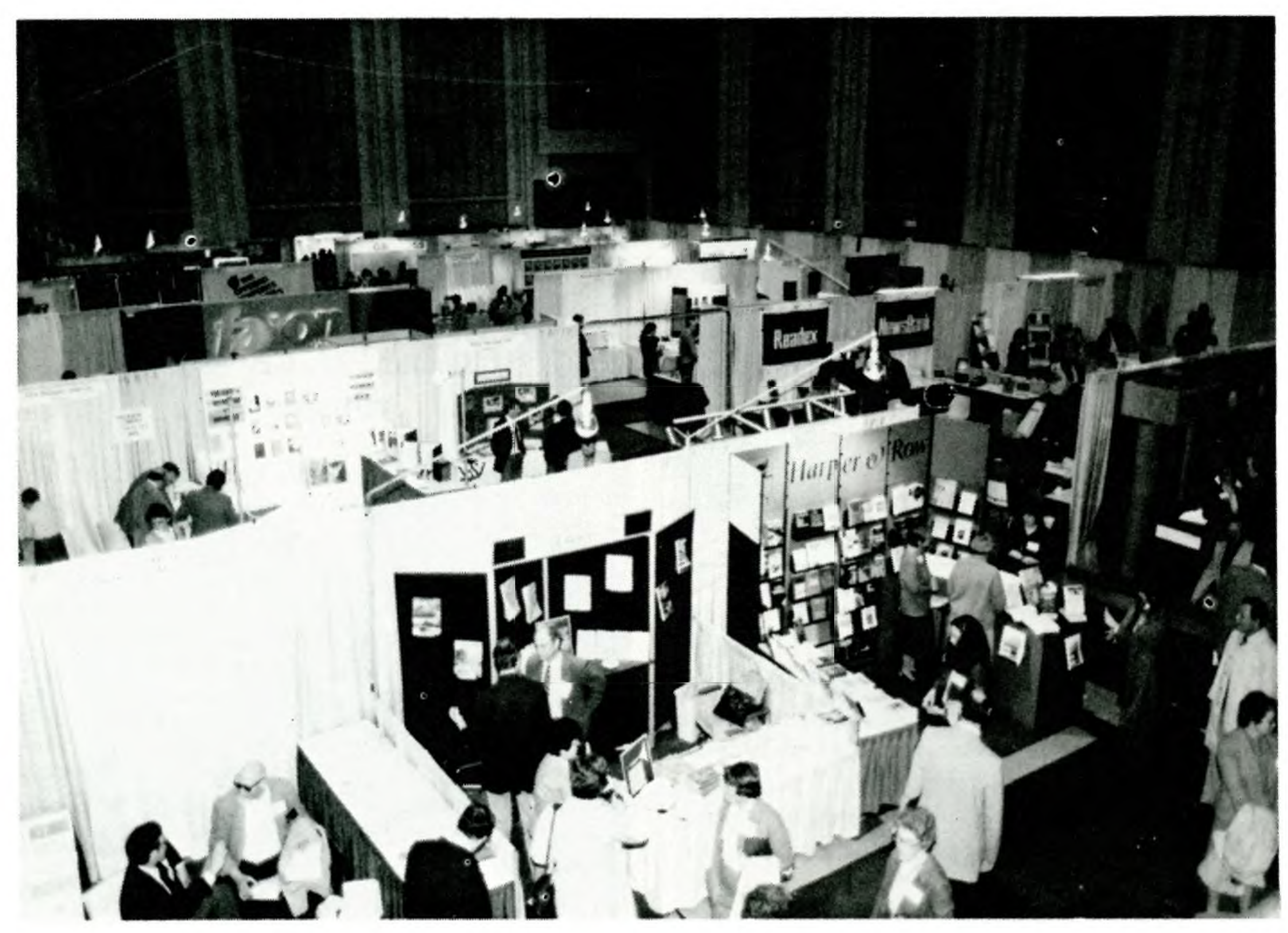

A bird's-eye view of the booths of some of the 125 companies that had exhibits at the Seattle Center. 
personal talents, their energies, and their professional skills count for something."

\section{Other conference notes}

- One innovation at the conference proved to be popular with both librarians and exhibitors. Four New Product Seminars allowed exhibitors to describe briefly the new products and services they were introducing in 1984 . The two seminars that highlighted new online services were especially well-attended.

- Four Alternative Format Sessions were presented in which a panel of speakers brought a variety of expertise to bear on such practical problems as comprehensive accesss to library holdings, public services, and automating a community college library. Gary Menges, chair of the National Conference Committee, explained the reasoning behind the sessions: "There had been criticism in the past of not having enough sessions of interest to community college librarians. The Alternative Format Sessions were a way of getting something specifically of interest to them, as there were only one or two contributed papers directly relating to community colleges."

- Cassette tapes of the theme addresses, the contributed paper sessions, and the alternative format sessions are available from Audio-Stats, $2639 \mathrm{~S}$. La Cienega Blvd., Los Angeles, CA 90034. A complete set costs $\$ 210$, but individual tapes are available for $\$ 7.50$ (plus shipping charges). Please refer to the Audio-Stat advertisement in the May $C \triangleleft R L$ News, pp. 252-53.

- The most unexpected moment at conference came when theme speaker William Moffett was suggesting that one reason why college librarians are not highly visible at ALA meetings might be that they enjoy their work too much to leave. Suddenly the lights in the ballroom dimmed and went out for a minute or two, as if an eerie force were challenging his assumption. In reality however, the lights had been doused accidentally by someone in the back of the room and it required a hotel technician to turn them back on. As Moffett quipped, "Well, at least we're not in the elevator."

-Conference exhibitors were generally pleased with the scheduling which allowed for several no-

\section{Logos available}

A serigraph version of the logo designed for the ACRL Third National Conference has been produced. Entitled "Thunderbird Trapped," the limited edition serigraph of 85 is printed on $100 \%$ rag paper. It may be ordered by writing to: Harry Calkins, 5217 Ivanhoe Place Northeast, Seattle, WA 98105.

The cost is $\$ 80$ plus $\$ 5$ for postage and handling. conflict hours that could be used for viewing exhibits. One company wrote that "we got every bit as much out of this convention as we put into itand that's a pretty good deal these days." Both the Exhibit Opening Reception, which featured a huge bowl of fortune cookies with library-related fortunes ("Always buy fiche on Fridays"), and the complimentary breakfasts in the exhibit hall encouraged browsing.

- Cathleen Krzyminski, ACRL's deputy executive director and conference assistant, seemed to be everywhere at once to make sure things ran smoothly. What was her most significant achievement? "It was our success in taking down the registration area completely each night and setting it up again in the morning to be open for business," she said. "That was definitely an amazing feat. I don't think many members realized that we did it, since the booths looked much the same from day to day."

-Many people remarked that their most memorable conference experiences were the China exhibit at the Pacific Science Museum and the huge salmon bake at the Kiana Lodge. Others listed the continuing education courses, the variety of contributed paper topics, and especially Seattle as a conference location, with its large concentration of bookstores, the hospitality of the natives, and its cosmopolitan flavor. Another member remarked, "It was much less hectic and pressured than ALA conferences and offered opportunities for meeting and talking with colleagues that are not possible at larger meetings."

- How successful was the conference? According to Gary Menges, "There are three elements that go into a successful conference. One is the program content-I think we were successful in that respect. The second element is holding the conference in a city that people enjoy and where there are things to do. The third element is all of the detail that goes into planning a conference-anticipating

\section{Bernard M. Fry Award announced}

Beginning with volume 11 (1984) Pergamon Press will offer a $\$ 500$ cash award to the author of the best article to appear each year in Government Publications Review. The award will be presented in honor of the founding editor of the journal, Bernard M. Fry, and will be chosen by the GPR Editorial Board on the basis of cogency, style, and significance of contribution to the field of government information.

The award will be announced at the general business meeting of the ALA Government Documents Round Table at ALA annual conferences. For additional information, contact Stephen D. Zink, Editor, Government Publications Review, University of Nevada Library, Reno, NV 89557-0044. 


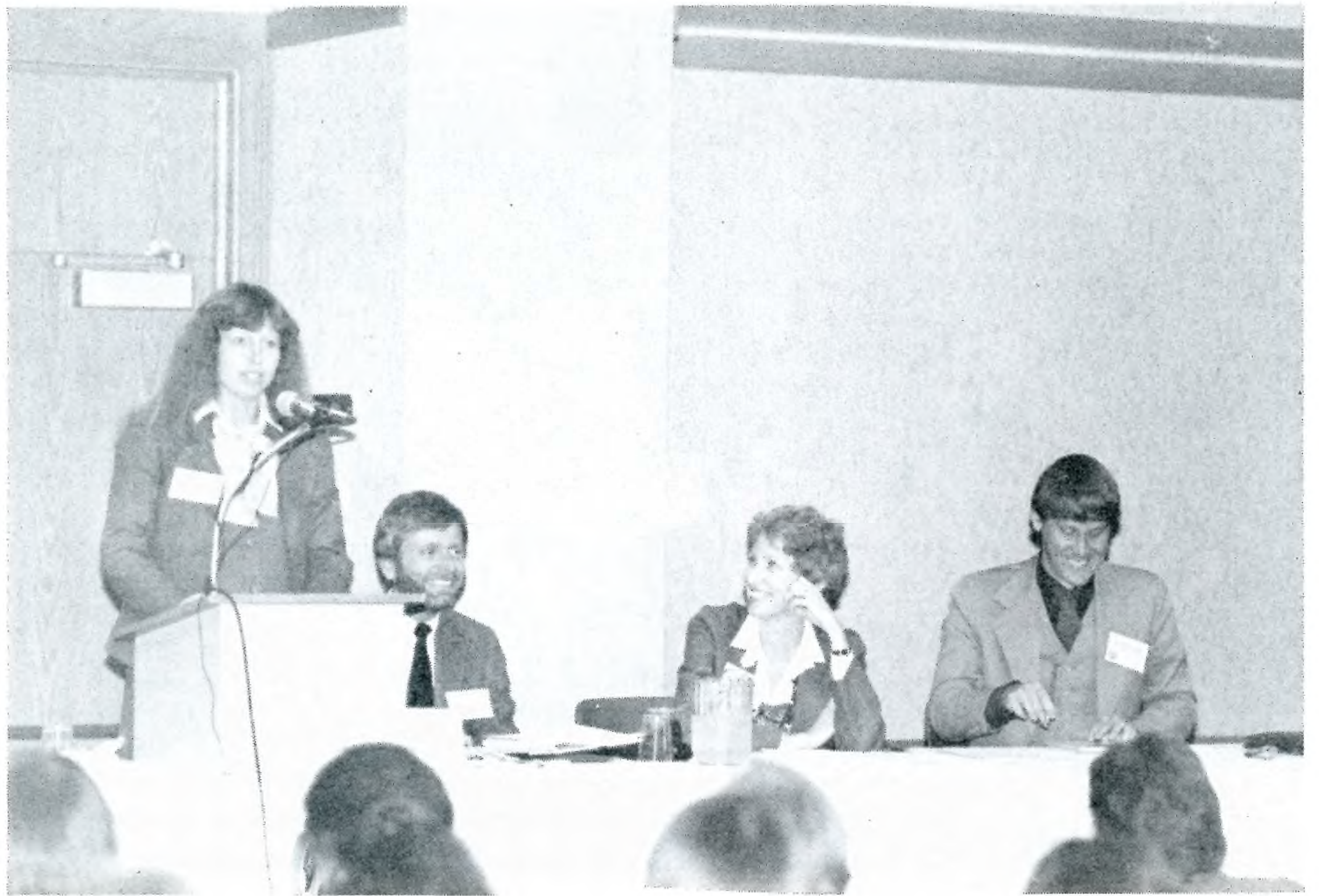

The Alternative Format Session on public services in research libraries: (l-r) Nancy Huling, Duane Webster, Patricia Swanson, and Cliff Haka.
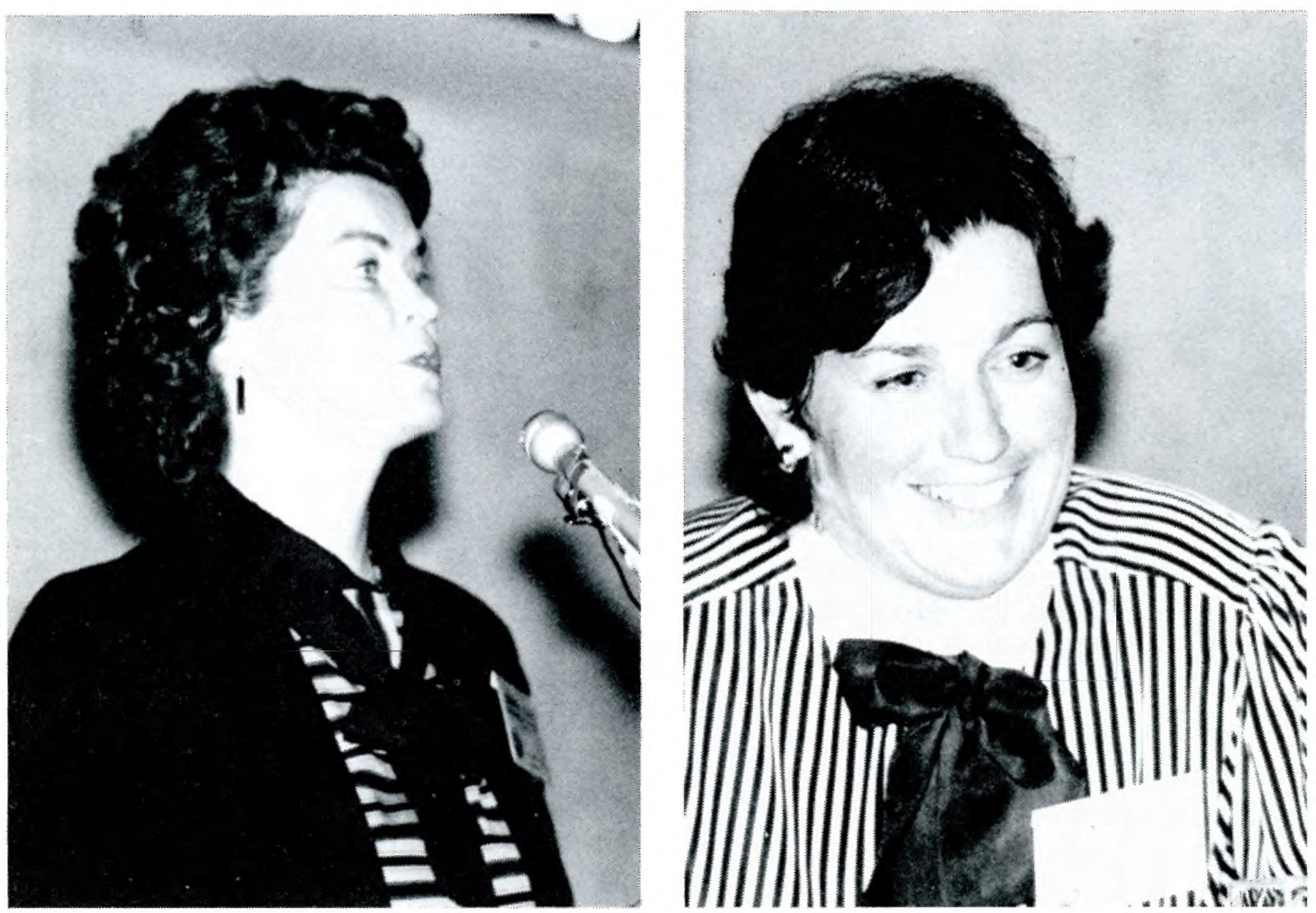

(l) Sharon Rogers, vice-president/president-elect of ACRL, moderates the Wrap-Up Session; (r) Mary Sue Farrell, CJCLS chair, Wrap-Up Session panelist. 


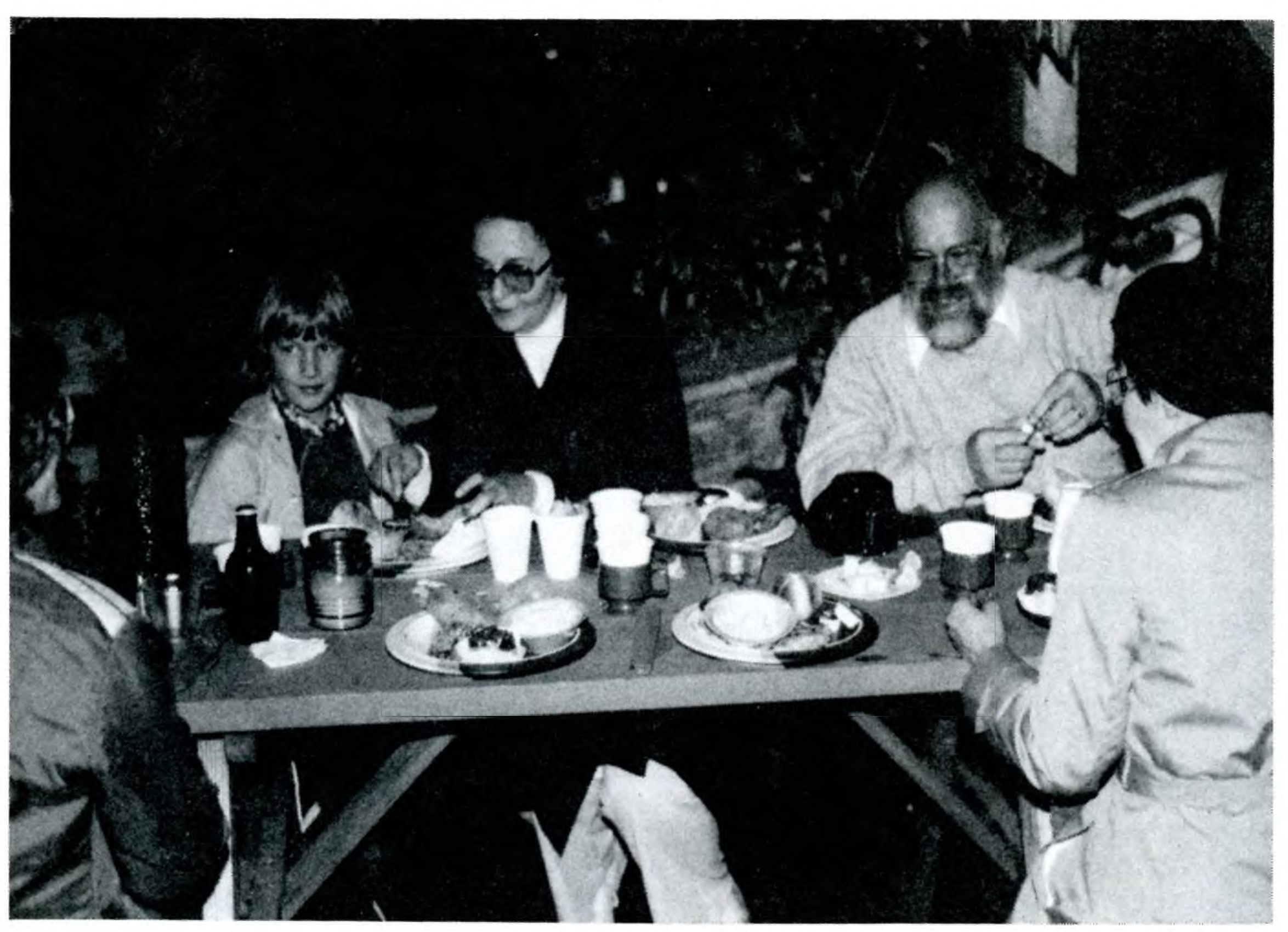

Conference-goers enjoying fresh salmon at the Kiana Lodge Salmon Bake.

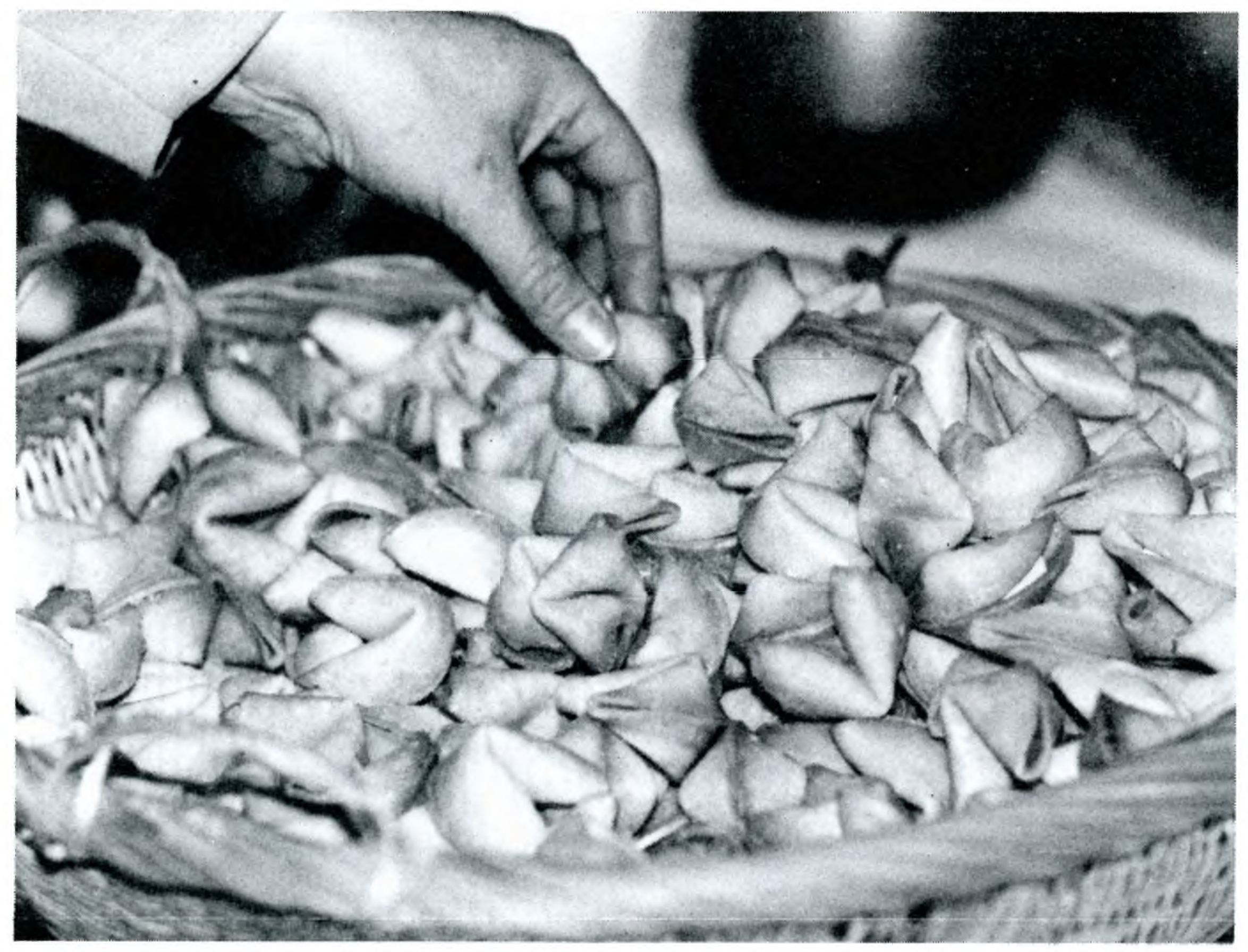

Will there be a tall, handsome online database salesperson in your life? Library-related fortune cookies hold the answer. 
the little things that people get annoyed at, like improper scheduling or inadequate audiovisual equipment. I think that in all these respects we came out very well."
-ACRL's Fourth National Conference will be held in Baltimore in April, 1986. We hope you will join us then when ACRL returns to the East. GME.

\title{
Using the online catalog effectively
}

\author{
By Marcella Stark \\ History and Afro-American Studies Librarian \\ Syracuse University
}

\section{A seminar, specifically designed for faculty members, on how to use the Syracuse University system.}

\begin{abstract}
$\mathbf{T}_{\mathrm{H}}$ he online public access catalog is becoming a reality in many institutions. Thus, instruction designed to show the capabilities of the online system is necessary, not only to overcome initial resistance to a new system, but also to ensure that the maximum capabilities of the system are apparent to users.

Librarians need to instruct faculty as well as students. Because they may find that faculty resist library instruction for themselves, librarians should seek reinforcements on the campus to aid in any instruction program. The following is a description of the Syracuse University Libraries cooperation with a respected campus institution to develop an instruction program for university faculty.

Syracuse University Libraries have had an online public access catalog, SULIRS (Syracuse University Libraries Information Retrieval System) since January 1981. Before the catalog was put in place, a slide-tape lecture, designed and presented by the director of libraries, prepared faculty for the change. There was publicity in the campus media. Users were provided with booklets that described basic searches.
\end{abstract}

At the outset the system provided author and tithe access only via OCLC derived search keys to a database of approximately 500,000. After five months, the search key approach was abandoned and SULIRS provided keyword searching via author, title, series title, call number, and subject. Free-text key word searching was possible across the title and subject fields. Initially, there were few HELP messages or system prompts imbedded in the SULIRS program; extensive HELP messages were added late in 1983. From the beginning, however, the Boolean AND was implied; the Boolean NOT being added later. ${ }^{1}$

SULIRS was available only in the libraries until the summer of 1983, when it was made available from any terminal on campus. Individuals with a terminal and modem could access SULIRS via the telephone and the university computing center.

Since most of the terminals in the library were located near the reference desk, reference librari-

${ }^{1}$ Gregory N. Bullard, "The Syracuse University Libraries Information Retrieval System," Research Libraries in OCLC: A Quarterly, no. 7 (1982):1-2. 